\title{
RELATIONSHIP BETWEEN TYPE OF AIRLINE AND WAGE OF PILOTS IN EUROPE
}

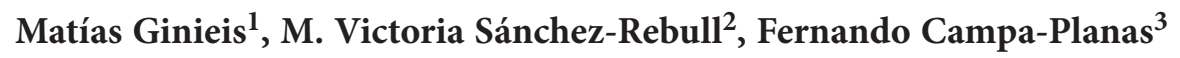 \\ Department of Business Management, Universitat Rovira i Virgili, Tarragona, Spain \\ E-mails: ${ }^{1}$ matias.ginieis@urv.cat (corresponding author); ${ }^{2}$ mariavictoria.sanchez@urv.cat; \\ 3 fernando.campa@urv.cat
}

Received 13 December 2012; accepted 22 January 2013

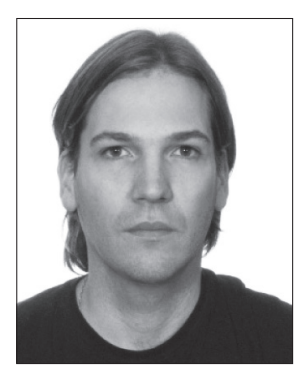

\section{Matías GINIEIS}

Education: National University of Mar del Plata, Argentina.

Affiliation and functions: doctoral student and teaching assistant at Rovira $i$ Virgili University, Spain, since 2009.

Research interests: transport aircraft performance, calculation of aircraft direct operating cost, economic geography, transport economics, cost management systems. Publications: author of five scientific articles.

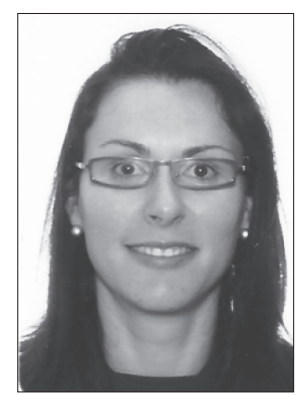

\section{Victoria SÁNCHEZ-REBULL, $D r$}

Education: University of Barcelona, Spain.

Affiliation and functions: head of the Department of Business Management and assistant professor at Rovira I Virgili University, Spain.

Research interests: aviation management, cost management systems, business administration, quality management, tourism.

Publications: author of over 20 scientific articles.

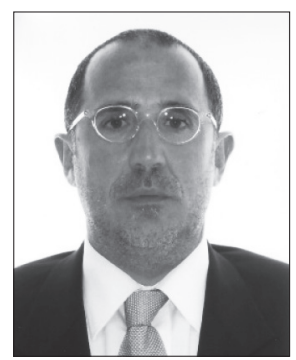

Fernando CAMPA-PLANAS, $D r$

Education: ESADE and University of Pompeu Fabra, Spain.

Affiliation and functions: assistant professor at Rovira I Virgili University, Spain.

Research interests: transport aircraft performance, business administration, aviation management, quality aviation, financial risk management.

Publications: author of over 20 scientific articles.

Abstract. The main objective of this work is to establish whether there are differences in airline pilots' salaries between the different types of airlines in Europe. With regard to airline type, the companies are categorised into traditional airlines (flag carriers and regular/regional/charter flights) and low-cost airlines. We have examined a total of 176 European airlines and analysed different categories of pilots (Captain Top, Captain Base, First Officer Top and First Officer Base). Two statistical tests were applied (the Haberman test and the chi-squared test) to demonstrate whether there is an association and dependence between types of airlines and pilots' salaries. The results show that there is association and dependence, from which we can deduce that the earnings of pilots are dependent upon the type of airline for which they work.

Keywords: air transportation, airline, wage, Haberman index, labour cost. 


\section{Introduction}

The air transportation industry makes an important contribution on an economic, political and social level. It is one of the most important sectors for a country's progress (Button 2008). The demand for air transportation is associated with economic growth, technological development, tourism and leisure, and the reduction of trade barriers between countries (Capobianco, Fernandes 2004).

This sector has experienced a process of deregulation that, according to most of the studies analysed (Alamdari, Morrell 1997; Button 2003; Gillen, Lall 2004), has been beneficial for its users. The liberalisation of the air transportation sector has led to an increase in available services, a drop in prices, and an increase in load factors, but also an increase in the external social costs caused by aviation.

Similarly, S. Tiernan, D. Rhoades and B. Waguespack point out that deregulation has transformed competition and, at the same time, given rise to the emergence of new leaders within the airline industry, due to measures such as the partial elimination of fare restrictions along with legislative and regulatory changes that have encouraged new low-cost carriers (LCC) (Tiernan et al. 2008). These airlines have considerably changed the competitive panorama, particularly because LCCs have expanded all over the world and have had a huge impact on air transportation markets (Macario et al. 2007).

E. Pels argues that traditional airlines (full service carriers - FSCs) offer 'quality', whereas the aim of LCCs is to keep costs as low as possible (Pels 2009). But with the increasing growth of LCCs, the FSCs have changed their business policies (European Cockpit Association 2006) and have been forced to implement reforms (pricing structures, cost-cutting, changes to on-board services, etc.) to adapt to this new and competitive scenario. Therefore, the emergence of LCCs in the air transportation market has brought with it a challenge for all airline companies to find ways of attracting passengers, by using strategies such as offering greater flexibility and discounts on fares, increasing the frequency of flights, and offering minimal on-board services. All these competitive strategies have an impact on cost recovery (Rose et al. 2005). In spite of this, the FSCs still have a certain competitive edge that differentiates them from their competitors: maintaining certain services that are highly rated by customers, such as free on-board meals, first-class seating, higher luggage allowances, etc.

D. Gillen and A. Lall established that the airlines that opted for a low-cost approach achieved these low costs through simplicity in product design and simplification of their organisational processes (Gillen, Lall 2004). They use the US airline Southwest as an example, which succeeded in reducing costs as a result of making their activ- ities less complex, thereby achieving greater efficiency through the simplification of operational processes. In Europe, the development of LCCs has been a major factor in the evolution of networks, competition and trends in the demand for air transport (Dobruszkes 2006).

According to R. Doganis, the airline industry since deregulation, first in the USA and later in Europe, indicates that 'cost reductions are no longer a short term answer to diminishing returns and falling load factors (Doganis 2001). They are a continuous and permanent requirement if airlines want to be profitable. Alamdari and Morrell (1997) point out that labour costs are one of the most strongly affected factors when there is a reduction in operating costs. They note that labour costs normally represent between one-third and one-quarter of the operating costs of airlines.

It is worth clarifying that the total difference in costs between LCCs and FSCs is not solely attributable to salary differences (Nadja 2003). There are numerous papers (Dobruszkes 2006; Button et al. 2007; de Neufville 2008; Tretheway 2011; etc.) on the subject of these differences. Our study focuses exclusively on the salaries of airline pilots and aims to establish the existence of a statistically significant relationship between salaries and the type of airline.

We believe, therefore, that the fact that labour costs represent a major factor in the operating expenses of airlines and that, in turn, the negotiations of the salary conditions of pilots, in particular, have repercussions that significantly transcend the scope of their own company provides sufficient reason to devote this study to analysing these costs. For this, we consider it interesting to study the knowledge area related to the personnel of airlines. Thus, our study aims to analyse the relationship between the salary paid to the different categories of pilots of different airlines and the type of airline (traditional (flag carriers and regular/regional/charter) and low-cost). To achieve this objective, the article is structured as follows. The second section reviews the existing literature in papers about labour costs, specifically pilots' salaries in the airline sector, and the third section puts forward the objectives and hypotheses of the study. Subsequently, the fourth section is devoted to methodology (definition of variables and data capture). The fifth section analyses the results obtained and finally the last section sets forth the main conclusions.

\section{Labour costs in the industry sector}

In the particular sector of air transport, there is evidence of a growing interest by academics in the broadly defined field of air transportation management (Ginieis et al. 2012). Most of these studies have been primarily developed in the USA (Alamdari, Morrell 1997; Tsoula- 
kas et al. 2008), a country that has a strong tradition in the competitive airline industry.

Different authors (Gudmundsson 2004; Chen 2008) argue that a company's organisational structure and labour flexibility contribute to the creation of a good brand image and to service quality by the airline. There are studies that focus on the ratio of staff costs and other input variables (such as kilometres per passengers, fuel consumption, flight equipment, and ground property and equipment) and show the relationship between these variables and various economic parameters such as productivity (Oum, Yu 1995, 1998; Oum et al. 2005; Greer 2008; Heracleous, Wirtz 2009), job performance (Feng, Wang 2000), performance of financial strategy and efficiency in the airline industry (Fernandes, Capobianco 2001), and quality of the service of strategic alliances (Tiernan et al. 2008).

There are some studies that have examined the influence of the type of airline (Tsoulakas et al. 2008) or the geographic zone (Alamdari, Morrell 1997) on the average labour costs in the airline industry. In the USA, from 1995 to 2006, the FSCs reduced their costs to increase their benefits, whereas the labour costs of the LCCs increased due to an aging fleet and staff becoming more senior (Tsoulakas et al. 2008). Meanwhile C. Barbot, A. Costa and E. Sochirca explains that LCCs are generally more efficient than regular companies because of the business model (Barbot et al. 2008).

The cost structure of an airline is similar in every airline company. In general, it is estimated that around half corresponds to fuel and personnel costs. Taking a more in-depth look at airline labour costs for the purpose of this study, we note that the pilots of almost every airline are paid an hourly rate based on their job role and/or rank (captain or first officer), years of experience, and the type of aircraft flown (Lee, Rupp 2007).

A report presented by the Secretary of State for Transport of the Ministry of Public Works of the Government of Spain in 2008 noted that pilot costs represented $7 \%$ and cabin crew a further $7 \%$ of the total expenses of traditional airlines (Secretary of State for Transport 2008). The authors W. M. Swan and N. Adler, who also made a classification of the costs of airlines, establishing that pilots represented around $12 \%$ and auxiliary air crew $10 \%$ of general airline expenses (Swan, Adler 2006). It should be noted that these costs differ between airlines for various reasons, such as flying hours, the collective agreement in place, and the home country of the airline, among many other factors.

Some authors have demonstrated that the LCCs pay their employees less than the FSCs. In this respect, Dobruszkes (2006) shows, based on information gathered from various researchers, organisations, unions and journalists, that LCC employees are paid less than their counterparts working for FSCs, despite having a greater workload. Nadja (2003) establishes that the labour costs of LCC companies such as Southwest and JetBlue Airways are 30-40\% lower than those of FSCs. In a report presented by the European Cockpit Association (2002), the average gross annual income of pilots of LCC airlines in Europe compared to the income of pilots of FSCs was approximately $27.33 \%$ lower $^{1}$. The report also points out that, on average, FSC pilots do $26.10 \%$ fewer flying hours than their counterparts in the LCC airlines.

We should differentiate between the total personnel cost of a company and the cost per worker. First, there are two main reasons to explain the higher personnel cost of FSCs compared to LCCs. The first is that FSCs operate long-haul flights. If flight crew and flight attendants are paid in terms of flying hours, this results in a higher salary cost. Furthermore, flights of more than eight hours require a double crew and a relief pilot (a third pilot), and flights of over twelve hours require a fourth pilot (Swan, Adler 2006).

A second reason is that because long-haul flights involve larger aircraft, they need more staff on board (attendants, pursers, etc.). In the USA and Europe, one attendant is required for every fifty seats (Civil Aviation Safety Authority 2010). This represents a higher salary cost. In this case, given that LCCs operate point-to-point with smaller aircraft, with fewer crew, and over shorter distances (flying time), they need fewer employees and hence the total staff cost is lower (Nadja 2003).

Meanwhile, the differences in the average cost of pilots of the different airlines could also be explained by a number of other reasons. One main reason could be that FSCs and LCCs frequently use different types of aircraft. If pilots are paid in terms of the type and size of aircraft they fly, pilots will earn more for flying larger aircraft (Doganis 2002).

Another reason to explain the average cost could be that FSCs usually recruit more experienced pilots (years of experience, flying hours, experience in piloting different types of aircraft, amongst others), which leads to higher salary costs than LCCs. Frank and Hutchens (1993) point out that there is no evidence to demonstrate that senior pilots are more productive than their junior counterparts, nor that they have better safety records, even though the former are paid several times more (Frank, Hutchens 1993).

Finally, various authors (Frank, Hutchens 1993; Crémieux 1996; Johnson, Anderson 2004) have noted that deregulation led to a drop in the salary levels of pilots of North American airlines. Crémieux (1996) points out that liberalisation had a very negative effect on the

\footnotetext{
${ }^{1}$ For data purposes, FSC airlines are understood as being Air France, British Airways, Iberia, Lufthansa and SAS. And as LCCs: BUZZ, Deutsche BA, easyJet, Germania and Ryanair.
} 
income of pilots and flight crew yet had no statistically significant effect on mechanics' salaries. Their study demonstrates that the salaries of US airline pilots were $12 \%$ and $22 \%$ below the levels that might have been predicted for 1985 and 1992, respectively, when there was no deregulation.

These arguments demonstrate the need to conduct a more in-depth analysis of the labour costs of the different categories of flight crew to provide new evidence on the subject. In this respect, we believe it is appropriate to establish, for this study, three types of airlines and various labour categories of pilots. In this way, we aim to study and compare, in a more rigorous manner, the figures relating to the salaries of pilots paid by the airlines. In this study we explore whether there is a relationship between the level of pilots' wages and the airline type. To do so, two hypotheses were formulated for this research:

$-\mathrm{H}_{0}$ : the type of airline and the salary level of pilots are independent of each other;

$-\mathrm{H}_{1}$ : there is an association between the type of airline and the salary level of pilots.

\section{Methodology}

In this section we describe the methodology used to reach the objective described earlier. First, we define the variables used and then go on to explain what sources were used to obtain the data; finally, the statistical tests applied to the data are presented.

\subsection{Definition of variables}

In this study we used categorical and quantitative variables. The quantitative variable is the average salary per pilot, while the categorical variable is the type of airline, for which the airlines in Europe have been classified into three types or groups of airline (the categorical variable).

\subsubsection{Categorical variable: type of airline}

The existence of different studies demonstrating that LCCs pay their employees (including the pilots they have under contract) less than FSCs has been mentioned. These analyses are not broken down into the different professional categories of pilots. They only compare LCCs with FSCs without distinguishing whether the latter are flag carriers or regular, regional or charter airlines.

A flag carrier is an airline that is closely associated or identified with a specific country (Beria et al. 2011) and also enjoys certain preferential rights or privileges granted by the government (Button et al. 2007). Regular (or traditional or legacy) airlines are differentiated from flag carrier in that they are not regarded as the representative airline of a particular country. In Spain, for example, the flag carrier is Iberia (privatised) while regular airlines would include Air Europa and Spanair ${ }^{2}$. In the UK, the flag carrier is British Airways and a regular airline would be Virgin Atlantic Airways or Thomas Cook Airlines. Re-

2 (Closed) Company bankrupt. Ceased operation on 28 January 2012. gional airlines are those that operate in regional areas, i.e. they only fly within a small geographical area (Halpern 2008) and thus provide an air transportation service to communities with insufficient demand (Santana 2009). Generally speaking, these are the feeder companies of a flag carrier or regular airline. A charter airline is one that does not market its services through the usual sales channels (Randøy, Strandenes 1997). They operate flights outside the usual scheduled times or flights operated by contractual agreement with a specific client and are associated with tour operators that offer various vacation packages (Halpern 2008). Most regular airlines also occasionally provide charter services if they have spare capacity.

Therefore, in our study the Type of Airline categorical variable has been divided into three sub-groups: flag carriers (FLAG), low-cost airlines (LCC), and regular/regional/charter airlines (RRC).

\subsubsection{Quantitative variable: average pilot salary}

Given that there are different categories of pilots within the different airlines, four categories of pilots have been identified to define the quantitative variable of the average pilot's salary, these being: Captain Top (CPT), Captain Base (CPB), First Officer Top (FOT), and First Officer Base (FOB) (Fig.). This classification should serve to compare the maximum and minimum figures relating to the salaries between (and within) pilot categories within the rank of airline captain and within the rank of co-pilot (first officer). In the category top pilots, we have included pilots and co-pilots with more than 15 years of experience. Those belonging to the base category have less experience. Likewise, to better observe the level of association between the variables, the quantitative variable 'pilots' salaries' was sub-divided into quartiles, this being the most widely used position measurement (very high, high, medium, and low).

To sum up, figure below shows how the analysis of the categorical variable (Type of Airline) was made against the quantitative variable (Pilot Salary) for 2008. This year was selected as being the one with the biggest range of figures available at the time the collection of the data took place.

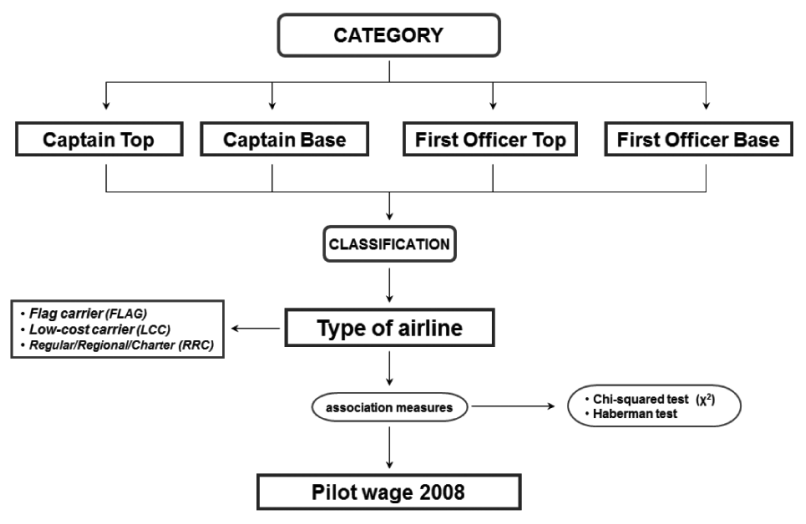

Fig. Degree of association between variables 


\subsection{Data capture}

The data on the average salaries of pilots was obtained following two criteria. First, data on pilots' salaries was taken from information published on the website of Pilot Jobs Network ${ }^{3}$. This website publishes general information on most of the airlines around the world. It is used to find job vacancies in the aviation industry both by working pilots and students from pilot schools who will shortly be joining the labour market. The site displays the different salaries of the airlines for consultation: first, for various years (information was not available for every year) and then monthly or annually. To homogenise the data, we opted for 2008 as the year of the study (base year). All the different airlines' salaries therefore had to be adjusted to that year. We examined a total of 176 airlines and analysed four different pilot categories.

In addition, we factored in the effect of inflation in each European country by correcting the different nominal values so that the figures would be comparable. The salaries from years before the base year (2008) were adjusted for inflation. Conversely, it was necessary to deflate the value of salaries from the following years. To make this adjustment, we took as a reference the different annual inflation indexes of the European countries on the Global Market Information Database (GMID), which in turn obtains its data from the International Monetary Fund.

\section{Results}

All the statistical analyses conducted in this study were done using the IBM SPSS Statistics 19 program. This was used to conduct the tests mentioned above and also to carry out an analysis of the mean values and standard deviations.

\subsection{Mean values and standard deviations}

In order to get a clearer idea of the significance of the salary values, we have included Table 1, which shows the mean value and standard deviation of each pilot category for each type of airline to which they belong (FLAG, LCC and RRC).

In table 1 we can see that on average the salaries paid by RRCs to their pilots in the four different categories are lower than those of the other two types of airlines, FLAG and LCC. Indeed, in some categories (Captain Top and First Officer Top), the salaries are much lower. A report issued by the European Cockpit Association (2006) indicates that flight crew salaries and pay scales differ considerably across the European aviation industry, and these differences are not related to the type of airline. It establishes that the salaries of pilots of an LCC can vary considerably and gives examples where the highest salary of a pilot with a certain LCC in Europe can be higher than in some charter companies and even come close to the pay scales of some of the FSCs.

In the categories of Captain Base (CPB) and First Officer Base (FOB), the mean values of the LCCs are even higher than the FLAGs; for example, the salary of the CPB in the LCCs is approximately $€ 76,603$, while that of the FLAGs is $€ 70,377$. The same situation occurs with the FOB, where the mean salary of LCC first officers $(€ 42,446)$ is higher than those of RRCs $(€ 40,978)$. In addition, we can see that in the case of FLAGs the CPBs, earning $€ 70,377$ per year, make on average less than the First Officer Top (FOT), earning €81,131. Similarly, it is worth noting the big difference in salaries between a FOT on a FLAG airline and one on an RRC (€52,302), around 55\% more.

Table 1 also shows that the biggest spread of salaries occurs in the CPT category in FLAGs (59.44), while the smallest is in the FOB category of the LCCs (12.98). The three categories in the FLAGs are those that show the most typical deviation, these being CPT (59.44), CPB (31.91) and FOT (45.73). Only in the FOB category do RCCs show a greater spread (14.45). Also, when compared with the other hierarchies, the salaries of the pilots in the FOB category show the highest concentration of salaries in the three airline types: FLAGs (13.22), LCCs (12.98) and RRCs (14.45).

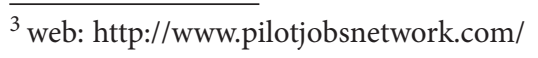

Table 1. Mean and standard deviation. Pilot average wage in 2008

\begin{tabular}{|c|c|c|c|c|c|c|c|c|c|}
\hline \multirow{3}{*}{ Variables } & \multicolumn{9}{|l|}{ Airlines } \\
\hline & \multicolumn{3}{|l|}{ FLAG } & \multicolumn{3}{|l|}{ LCC } & \multicolumn{3}{|l|}{ RRC } \\
\hline & Mean $(€)$ & Std. Dev. & Obs. & Mean $(€)$ & Std. Dev. & Obs. & Mean $(€)$ & Std. Dev. & Obs. \\
\hline Captain Top & $116,355.72$ & 59.44 & 21 & $110,783.86$ & 37.63 & 28 & $87,438.95$ & 35.98 & 85 \\
\hline Captain Base & $70,377.83$ & 31.91 & 23 & $76,603.43$ & 20.17 & 34 & $60,409.25$ & 24.26 & 91 \\
\hline First Officer Top & $81,131.16$ & 45.73 & 18 & $64,269.32$ & 25.24 & 32 & $52,302.26$ & 24.01 & 77 \\
\hline First Officer Base & $40,978.02$ & 13.22 & 24 & $42,446.49$ & 12.98 & 34 & $34,373.59$ & 14.45 & 98 \\
\hline
\end{tabular}

Source: Authors. 


\subsection{Chi-squared $\left(\chi^{2}\right)$ test and Haberman's adjusted residual test}

Next, an analysis was done of the statistical significance and relationship between the variables for each category individually, in order to better observe each relationship. As mentioned earlier, Pearson's chi-squared $\left(\chi^{2}\right)$ test was chosen as being the most widely used test for independence (or relationship) between two variables being analysed. Then the Haberman test was applied to interpret precisely the significance of the relationship identified. This test establishes that if the values are greater in absolute value than \pm 1.96 , they have a $95 \%$ chance of not being random and of being significant. Thus, the greater the value of the residual is, the greater the difference is. The sign of the value indicates the direction of the relationship. Residuals greater than 1.96 reveal check boxes with more cases than there should have been in that box if the variables studied were independent. Residuals below -1.96 , meanwhile, reveal check boxes with fewer cases than those that could have been anticipated if independent.

Below, an analysis is made of the results obtained, differentiated by each category of pilot studied and their relationship to the type of airline.

\subsubsection{Captain Top 2008}

First, the cases used to analyse the pilot category Captain Top 2008 (CPT) comprised a total sample of 134 cases, of which 21 correspond to flag carriers (FLAG), 28 to LCCs and 85 to regular/regional/charter airlines (RRCs). The values used to define the quartiles are as follows: very high salaries ( $\geq € 125,500)$, high salaries (€89,750-€125,499), average salaries (€64,500-€89,749) and low salaries $(\leq € 64,499)$.

Once the intervals for studying the CPT variable had been defined, Pearson's chi-squared $\left(\chi^{2}\right)$ test was conducted to check the independence or dependence between the two variables (Tab. 2).
This test shows that there was a relationship between the type of airline and the salaries of CPT pilots in 2008 (value obtained from the asymptotic significance (bilateral) $=0.007<\alpha=0.05)$. Therefore, the null hypothesis is rejected $\left(\mathrm{H}_{0}\right)$. Furthermore, the previous result can be corroborated with the $\chi^{2}$ distribution table. The chi-squared value obtained, equivalent to 17.589 , is compared with the value given in the aforementioned $\chi^{2}$ table (12.5916). Since it is greater, the alternative hypothesis $\left(\mathrm{H}_{1}\right)$ of association between variables is accepted.

Table 2. Captain Top 2008. Chi-Square tests by type of airline

\begin{tabular}{llll}
\hline & Value & df & Asymp. Sig. \\
\hline Pearson Chi-Squared & $17.589^{\mathrm{a}}$ & 6 & 0.007 \\
\hline Likelihood Ratio & 18.002 & 6 & 0.006 \\
\hline Linear-by-Linear Association & 6.136 & 1 & 0.013 \\
\hline N of Valid Cases & 134 & & \\
\hline
\end{tabular}

a. 0 cells $(.0 \%)$ have an expected count less than 5 . The minimum expected count is 5.17 .

Source: Authors.

Next, with the use of Haberman's adjusted residual test, an analysis was made of which salary scales produce the association between these variables. In the adjusted residuals table below (Tab. 3), we can see from which category of salaries statistical significance is obtained among the variables.

The results show the cases in which the relationship is not due to chance. This applies to the FLAG carriers that pay very high annual salaries to their pilots, more than $€ 125,500$; the LCCs where the pilots are paid a high annual salary, between $€ 89,750$ and $€ 125,499$; the RRC airlines that pay very high annual salaries to their pilots, over $€ 125,500$; and the RRCs where pilots earn a midlevel annual salary of between $€ 64,500$ and $€ 89,749$.

Thus the association between the variables of airline type and 2008 pilots' salaries in the Captain Top pilot category does not seem to be random.

Table 3. Captain Top 2008. Crosstabs adjusted and standardised by type

\begin{tabular}{|c|c|c|c|c|c|c|}
\hline & & & \multicolumn{3}{|c|}{ Type of Airline } & \multirow{2}{*}{ Total } \\
\hline & & & FLAG & LCC & RRC & \\
\hline \multirow[t]{12}{*}{ Pilot Wage } & Very High & Count & 9 & 9 & 15 & 33 \\
\hline & & $\%$ of Total & $6.7 \%$ & $6.7 \%$ & $11.2 \%$ & $24.6 \%$ \\
\hline & & Adjusted Residual & 2.1 & 1.0 & -2.5 & \\
\hline & High & Count & 4 & 12 & 18 & 34 \\
\hline & & $\%$ of Total & $3.0 \%$ & $9.0 \%$ & $13.4 \%$ & $25.4 \%$ \\
\hline & & Adjusted Residual & -0.7 & 2.4 & -1.5 & \\
\hline & Medium & Count & 2 & 4 & 28 & 34 \\
\hline & & $\%$ of Total & $1.5 \%$ & $3.0 \%$ & $20.9 \%$ & $25.4 \%$ \\
\hline & & Adjusted Residual & -1.8 & -1.5 & 2.7 & \\
\hline & Low & Count & 6 & 3 & 24 & 33 \\
\hline & & $\%$ of Total & $4.5 \%$ & $2.2 \%$ & $17.9 \%$ & $24.6 \%$ \\
\hline & & Adjusted Residual & 0.5 & -1.9 & 1.3 & \\
\hline \multirow[t]{2}{*}{ Total } & & Count & 21 & 28 & 85 & 134 \\
\hline & & $\%$ of Total & $15.7 \%$ & $20.9 \%$ & $63.4 \%$ & $100.0 \%$ \\
\hline
\end{tabular}


Table 3 shows that there is a positive relationship between the type of airline FLAG and the category CPT (value $=2.1$ ). This means that the FLAGs are characterised by paying very high salaries to their pilots. Likewise, it is worth mentioning that the RRCs $(-2.5)$ pay medium salaries to their pilots (2.7) and the LCCs pay their pilots high wages (2.4).

\subsubsection{Captain Base 2008}

For the Captain Base category of employees, the cases used for analysis comprised a sample of 148 cases, of which 23 correspond to FLAGs, 34 to LCCs and 91 to RRCs. The values obtained in the four intervals were very high salaries $(\geq € 85,000)$, high $(€ 63,900-€ 84,999)$, medium (€48,000-€63,899) and low ( $\leq € 47,999)$.

From the results obtained from the chi-squared test (Tab. 4), we conclude that there was a relationship between the variables of airline type and of pilots' salaries in 2008 (the asymptotic significance is equivalent to $0.021<a=0.05)$. Because of this, the null hypothesis is rejected $\left(\mathrm{H}_{0}\right)$. Furthermore, it is confirmed by the $\chi^{2}$ distribution table (12.5916 less than 14.872). The association between the variables is, therefore, accepted.

Table 4. Captain Base 2008. Chi-squared tests by type of airline

\begin{tabular}{llll}
\hline & Value & $\mathrm{df}$ & Asymp. Sig. \\
Pearson Chi-Squared & $14.872^{\mathrm{a}}$ & 6 & 0.021 \\
\hline Likelihood Ratio & 16.616 & 6 & 0.011 \\
\hline Linear-by-Linear Association & 6.001 & 1 & 0.014 \\
\hline N of Valid Cases & 148 & & \\
\hline
\end{tabular}

a. 0 cells (.0\%) have an expected count less than 5 . The minimum expected count is 5.75 .

Source: Authors.

By applying Haberman's adjusted residual test, we obtained the following table 5 .
The results demonstrate the cases in which the relationship is not due to chance. These cases are primarily the LCCs that pay very high annual salaries to their pilots, over $€ 85,000$; the LCCs that pay very low annual salaries to their pilots, less than $€ 47,999$; the RRCs that pay very high annual salaries to their pilots, over $€ 85,000$; and the RRCs that pay very low annual salaries to their pilots, less than $€ 47,999$.

The conclusion would be that statistical significance is obtained in two types of airline (LCCs and RRCs) and that it only occurs at low or very high salaries. But the association in this category of pilots is confirmed in the reverse way. LCCs are found to pay very high salaries (2.5) and they do not pay low salaries (-2.9). On the contrary, RRCs are found to pay low salaries (2.4) and they do not pay high salaries (-2.6).

\subsubsection{First Officer Top 2008}

The First Officer Top (FOT) pilot category is subdivided into the following quartiles: very high salaries $(\geq € 78,500)$, high $(€ 52,400-€ 78,499)$, medium $(€ 36,000-$ $€ 52,399)$ and low $(\leq € 35,999)$. The statistical tests produced the following results (Tab. 6).

Table 6. First Officer Top 2008. Chi-Squared tests by type of airline

\begin{tabular}{llll}
\hline & Value & df & Asymp. Sig. \\
Pearson Chi-Squared & $12.361^{\mathrm{a}}$ & 6 & 0.054 \\
\hline Likelihood Ratio & 12.072 & 6 & 0.060 \\
\hline Linear-by-Linear Association & 8.742 & 1 & 0.003 \\
\hline N of Valid Cases & 127 & \\
\hline a. 4 cells (33.3\%) have an expected count less than 5. \\
The minimum expected count is 4.39. \\
Source: Authors.
\end{tabular}

In contrast to the two previous cases, there is independence between the variables of airline type and

Table 5. Captain Base 2008. Crosstabs adjusted and standardised by type

\begin{tabular}{|c|c|c|c|c|c|c|}
\hline & & & \multicolumn{3}{|c|}{ Type of Airline } & \multirow{2}{*}{ Total } \\
\hline & & & FLAG & LCC & RRC & \\
\hline \multirow[t]{12}{*}{ Pilot Wage } & Very High & Count & 7 & 14 & 16 & 37 \\
\hline & & $\%$ of Total & $4.7 \%$ & $9.5 \%$ & $10.8 \%$ & $25.0 \%$ \\
\hline & & Adjusted Residual & 0.7 & $2.5)$ & -2.6 & \\
\hline & High & Count & 6 & 11 & 20 & 37 \\
\hline & & $\%$ of Total & $4.1 \%$ & $7.4 \%$ & $13.5 \%$ & $25.0 \%$ \\
\hline & & Adjusted Residual & 0.1 & 1.1 & -1.1 & \\
\hline & Medium & Count & 4 & 7 & 26 & 37 \\
\hline & & $\%$ of Total & $2.7 \%$ & $4.7 \%$ & $17.6 \%$ & $25.0 \%$ \\
\hline & & Adjusted Residual & -0.9 & -0.7 & 1.3 & \\
\hline & Low & Count & 6 & 2 & 29 & 37 \\
\hline & & $\%$ of Total & $4.1 \%$ & $1.4 \%$ & $19.6 \%$ & $25.0 \%$ \\
\hline & & Adjusted Residual & 0.1 & -2.9 & 2.4 & \\
\hline \multirow[t]{2}{*}{ Total } & & Count & 23 & 34 & 91 & 148 \\
\hline & & $\%$ of Total & $15.5 \%$ & $23.0 \%$ & $61.5 \%$ & $100.0 \%$ \\
\hline
\end{tabular}

Source: Authors. 
Table 7. First Officer Top 2008. Cross tabs adjusted and standardised by type

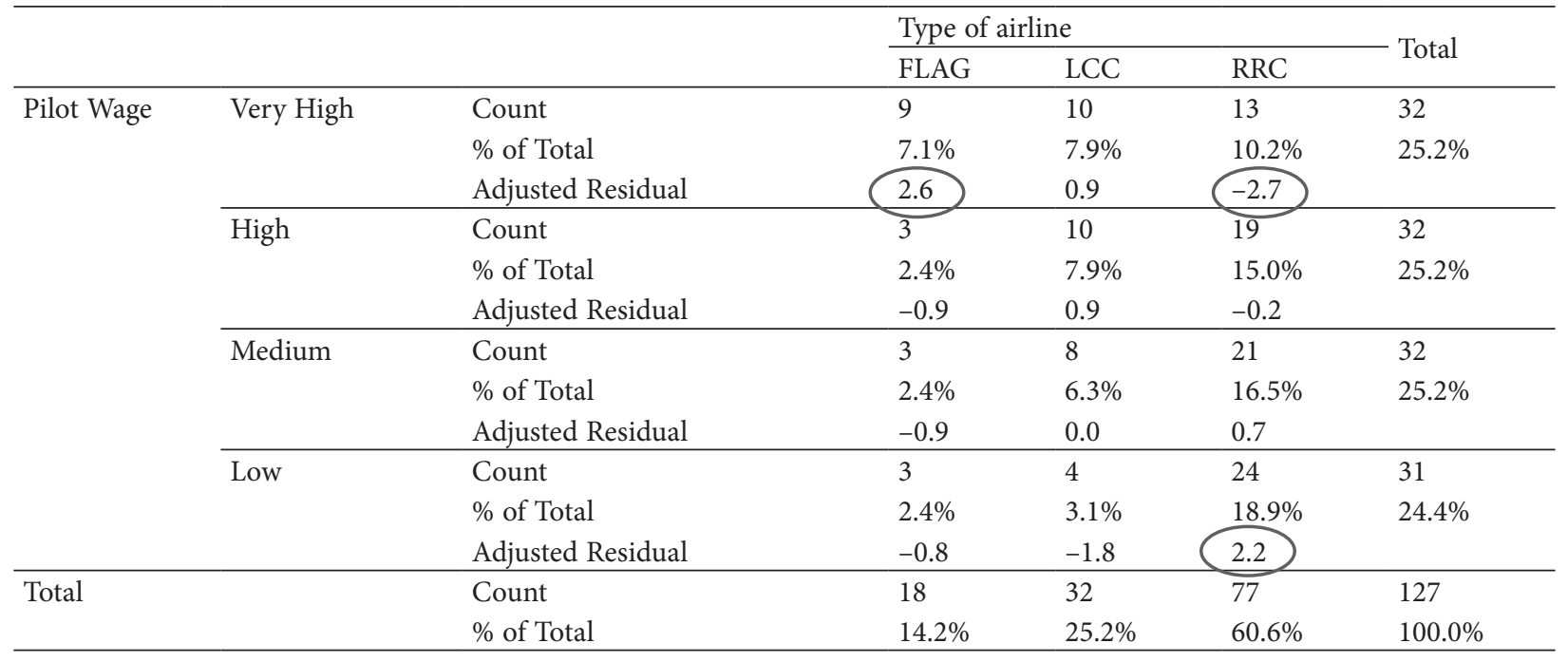

Source: Authors.

salaries of pilots (asymptotic significance $=0.054>$ significance level of $\alpha=0.05)$. The null hypothesis $\left(\mathrm{H}_{0}\right)$ of independence between variables is therefore accepted. The previous result is verified by the $\chi^{2}$ distribution table by making a comparison with the chi-squared value obtained in table 6, equivalent to 12.361 and being less than the value shown in the $\chi^{2}$ distribution table (12.5916). We also accept, therefore, the $\mathrm{H}_{0}$ of independence between variables.

In this case, since the independence between variables had already been tested, it was not necessary to apply Haberman's test. Nevertheless, it was still used to observe, in the event that a relationship did exist, at which salary levels it occurred. The cases used for analysis comprised a sample of 127 cases, of which 18 were with FLAGs, 32 with LCCs, and finally 77 with RRCs. The application of the test (Tab. 7) demonstrates that a relationship only occurs in two types of airlines: FLAG (at one level - very high) and RRC (two levels - very high and low).

\subsubsection{First Officer Base 2008}

We lastly applied the same analyses to the employee category of First Officer Base (FOB). The salary levels for the four intervals are as follows: very high $(\geq € 48,000)$, high (€36,120-€47,999), medium (€26,200-€36,119) and low $(\leq € 26,199)$. The chi-squared test produced the following result (Tab. 8).

These results demonstrate that there was an association between type of airline and the salaries of this pilot category in 2008 (asymptotic significance value $=0.006$, $<a=0.05)$. The null hypothesis $\left(\mathrm{H}_{0}\right)$ is therefore rejected. If we observe the value in the $\chi^{2}$ distribution table (12.5916), it is less than the chi-squared value obtained in table 8 (17.944). The $\mathrm{H}_{1}$ of association between variables is therefore also accepted.
Table 8. First Officer Base 2008. Chi-Squared tests by type of airline

\begin{tabular}{llll}
\hline & Value & df & Asymp. Sig. \\
Pearson Chi-Squared & $17.944^{\mathrm{a}}$ & 6 & 0.006 \\
\hline Likelihood Ratio & 18.463 & 6 & 0.005 \\
\hline Linear-by-Linear Association & 10.574 & 1 & 0.001 \\
\hline N of Valid Cases & 156 & & \\
\hline
\end{tabular}

a. 0 cells $(.0 \%)$ have an expected count less than 5 . The minimum expected count is 6.00 .

Source: Authors

Subsequently the Haberman adjusted residuals test was applied. In table 9 there are 156 cases, of which 24 belong to FLAGs, 34 to LCCs, and finally 98 to RRCs.

In table 9 we can see that in this pilot category the association between variables is evident at practically every salary level (very high, high, medium, and low) in airline types LCC and RRC. LCCs pay very high or high salaries (2.0 in both cases), and the RRCs are found to pay medium (2.1) or low (2.5) salaries.

\section{Conclusions}

Some reports have concluded that LCCs have lower flight crew costs than FSCs. In undertaking this study, we subdivided the salaries examined into four pilot categories and demonstrated that the Captain Top and First Officer Top categories belonging to flag carriers (FLAG) are those who are best paid. Nevertheless, Captain Base and First Officer Base pilots with LCCs are the highest paid in their categories. Meanwhile, RCCs are always those that pay the lowest salaries to their pilots. It is worth highlighting that FLAGs generally have the widest range of salaries paid to pilots.

On verifying whether there is a relationship between types of airline and pilots' salaries, we can see that three of the four categories of pilot are associated with the salary levels paid by the airlines to their pilots. 
Table 9. First Officer Base 2008. Cross tabs adjusted and standardised by type

\begin{tabular}{|c|c|c|c|c|c|c|}
\hline & & & Type o & & & Total \\
\hline & & & FLAG & LCC & RRC & Iotal \\
\hline Pilot Wage & Very High & Count & 9 & 13 & 17 & 39 \\
\hline & & $\%$ of Total & $5.8 \%$ & $8.3 \%$ & $10.9 \%$ & $25.0 \%$ \\
\hline & & Adjusted Residual & 1.5 & 2.0 & -2.9 & \\
\hline & High & Count & 6 & 13 & 20 & 39 \\
\hline & & $\%$ of Total & $3.8 \%$ & $8.3 \%$ & $12.8 \%$ & $25.0 \%$ \\
\hline & & Adjusted Residual & 0.0 & 2.0 & -1.7 & \\
\hline & Medium & Count & 5 & 4 & 30 & 39 \\
\hline & & $\%$ of Total & $3.2 \%$ & $2.6 \%$ & $19.2 \%$ & $25.0 \%$ \\
\hline & & Adjusted Residual & -0.5 & $-2.0)$ & 2.1 & \\
\hline & Low & Count & 4 & 4 & 31 & 39 \\
\hline & & $\%$ of Total & $2.6 \%$ & $2.6 \%$ & $19.9 \%$ & $25.0 \%$ \\
\hline & & Adjusted Residual & -1.0 & $-2.0)$ & 2.5 & \\
\hline Total & & Count & 24 & 34 & 98 & 156 \\
\hline & & $\%$ of Total & $15.4 \%$ & $21.8 \%$ & $62.8 \%$ & $100.0 \%$ \\
\hline
\end{tabular}

Source: Authors.

Only one case (FOT) did not produce an association between the variables. In general, it appears that in the pilot categories where an association exists (CPT, $\mathrm{CPB}$ and FOB), the relationship between the variables is most evident in airline types LCC and RRC and that it occurs at the extremes of the salary levels (very high or low). It is worth noting that in the FOB category this relationship is evident at practically every pilot salary level in airline types LCC and RRC.

Finally, it should be noted that this research can be drawn up and compared with information from different years, whether taking previous periods into consideration or comparing the analysis with more recent years. Likewise, in the future similar investigations could be carried out in other areas outside Europe, for example in the USA, where competition in the airline sector started with the industry's deregulation in 1979, while in Europe the liberalisation of the skies did not happen until the 1990s, or even in Asia, since this is a region in the midst of strong growth in terms of competition between airlines.

With regard to the limitations of this work, it should first be pointed out that the comparison was made for the different levels of salaries in one particular year, 2008, so it would be worthwhile conducting new studies with more up-to-date information. A rigorous distinction is not made between salary figures in terms of whether they related to gross or net salary, nor is it specified whether the salary included any kind of bonus for length of service. Also, no distinction is made with regard to the kind of aircraft to which pilots' salaries corresponded (narrow-bodied or wide-bodied) or whether the salaries correspond to pilots flying short, long or medium distances. Furthermore, the impact of different social and taxation implications on pilots' salaries in the different European countries should also be analysed. A report from the European Cockpit Association (2006) states that the main differentiating factor in the extra costs of flight crew is the lack of harmonisation of the social and taxation situation in Europe. Labour costs are to a great extent determined by these laws, which means that a comparison of the pure salary scale may not be representative.

\section{References}

Alamdari, F.; Morrell, P. 1997. Airline labour cost reduction: post-liberalisation experience USA and Europe, Journal of Air Transport Management 3(2): 53-66. http://dx.doi.org/10.1016/S0969-6997(97)00024-0

Barbot, C.; Costa, A.; Sochirca, E. 2008. Airlines performance in the new market context: a comparative productivity and efficiency analysis, Journal of Air Transport Management 14(5): 270-274.

http://dx.doi.org/10.1016/j.jairtraman.2008.05.003

Beria, P.; Niemeier, H.-M.; Fröhlich, K. 2011. Alitalia - the failure of a national carrier, Journal of Air Transport Management 17(4): 215-220. http://dx.doi.org/10.1016/j.jairtraman.2011.02.007

Button, K, 2003. Does the theory of the 'core' explain why airlines fail to cover their long-run costs of capital?, Journal of Air Transport Management 9(1): 5-14. http://dx.doi.org/10.1016/S0969-6997(02)00075-3

Button, K.; Costa, A.; Cruz, C. 2007. Ability to recover full costs through price discrimination in deregulated scheduled air transport markets, Transport Reviews 27(2): 213230. http://dx.doi.org/10.1080/01441640600951949

Button, K. 2008. The impacts of globalisation on international air transport activity. Past trends and future perspectives, in Global Forum on Transport and Environment in a Globalising World. 10-12 November 2008, Guadalajara, Mexico [online]. [Cited 13 March 2012]. Available from Internet: http://www.oecd.org/env/transportandenvironment/41373470.pdf

Capobianco, H. M. P.; Fernandes, E. 2004. Capital structure in the world airline industry, Transportation Research Part A: Policy and Practice 38(6): 421-434. http://dx.doi.org/10.1016/j.tra.2004.03.002 
Chen, C.-F. 2008. Investigating structural relationships between service quality, perceived value, satisfaction, and behavioral intentions for air passengers: evidence from Taiwan, Transportation Research Part A: Policy and Practice 42(4): 709-717. http://dx.doi.org/10.1016/j.tra.2008.01.007

Civil Aviation Safety Authority. 2010. Proposed civil aviation advisory publication. Cabin Crew Ratios. CASA, Annex B. CAAP 208-1(0) [online]. [Cited 11 October 2012]. Available from Internet: http://www.casa.gov.au/wcmswr/_assets/main/newrules/ops/nprm/0905os_annex_b.pdf

Crémieux, P.-Y. 1996. The effect of deregulation on employee earnings: pilots, flight attendants, and mechanics, 1959-1992, Industrial and Labor Relations Review 49(2): 223-242. http://dx.doi.org/10.2307/2524940

de Neufville, R. 2008. Low-cost airports for low-cost airlines: Flexible design to manage the risks, Transportation Planning and Technology [online] 31(1): 35-68. [Cited 1 April 2012]. Available from Internet: http://ardent.mit.edu/ airports/ASP_papers/JTP\%20low-cost\%20airports\%20 paper\%20March.pdf

Dobruszkes, F. 2006. An analysis of European low-cost airlines and their networks, Journal of Transport Geography 14(4): 249-264. http://dx.doi.org/10.1016/j.jtrangeo.2005.08.005

Doganis, R. 2001. The Airline Business. London: Routledge.

Doganis, R. 2002. Flying off Course. The Economics of International Airlines. London: Routledge.

European Cockpit Association. 2002. Low cost carriers in the European aviation single market [online]. ECA Industrial Sub Group. September 2002. Brussels, Belgium. [Cited 15 March 2012] Available from Internet: http://www.aerohabitat.eu/uploads/media/08-08-2005_-_ECA__Low_cost_ carrier_in_UE_1MB_.pdf

European Cockpit Association. 2006. Upheaval in the European skies. Low cost carriers in Europe: economic data, market and pilot demand forecast [online]. ECA Industrial Sub Group. June 2006. Brussels, Belgium [Cited 28 May 2012]. Available from Internet: http://www.eurocockpit.be/sites/ default/files/LCC-Book-2006-Final-Web.pdf

Feng, C.-M.; Wang, R.-T. 2000. Performance evaluation for airlines including the consideration of financial ratios, Journal of Air Transport Management 6(3): 133-142. http://dx.doi.org/10.1016/S0969-6997(00)00003-X

Fernandes, E.; Capobianco, H. M. P. 2001. Airline capital structure and returns, Journal of Air Transport Management 7(3): 137-142. http://dx.doi.org/10.1016/S0969-6997(00)00041-7

Frank, R. H.; Hutchens, R. M. 1993. Wages, seniority, and the demand for rising consumption profiles, Journal of Economic Behavior and Organization 21(3): 251-276. http://dx.doi.org/10.1016/0167-2681(93)90052-Q

Gillen, D, Lall, A. 2004. Competitive advantage of low-cost carriers: some implications for airports, Journal of Air Transport Management 10(1): 41-50. http://dx.doi.org/10.1016/j.jairtraman.2003.10.009

Ginieis, M.; Sánchez-Rebull, M. V.; Campa-Planas, F. 2012. The academic journal literature on air transport: Analysis using systematic literature review methodology, Journal of Air Transport Management 19: 31-35.

http://dx.doi.org/10.1016/j.jairtraman.2011.12.005

Greer, M. R. 2008. Nothing focuses the mind on productivity quite like the fear of liquidation: changes in airline productivity in the United States, 2000-2004, Transportation Research Part A: Policy and Practice 42(2): 414-426. http://dx.doi.org/10.1016/j.tra.2007.11.001
Gudmundsson, S. V. 2004. Management emphasis and performance in the airline industry: an exploratory multilevel analysis, Transportation Research Part E: Logistics and Transportation Review 40(6): 443-463.

http://dx.doi.org/10.1016/j.tre.2004.08.004

Halpern, N. 2008. Lapland's airports: facilitating the development of international tourism in a peripheral region, Scandinavian Journal of Hospitality and Tourism 8(1): 25-47. http://dx.doi.org/10.1080/15022250801987762

Heracleous, L.; Wirtz, J. 2009. Strategy and organization at Singapore Airlines: achieving sustainable advantage through dual strategy, Journal of Air Transport Management 15(6): 274-279. http://dx.doi.org/10.1016/j.jairtraman.2008.11.011

Johnson, N. B.; Anderson, J. R. 2004. Airline employment, productivity, and working conditions following deregulation, Research in Transportation Economics 10(1): 79-108. http://dx.doi.org/10.1016/S0739-8859(04)10005-X

Lee, D.; Rupp, N. 2007. Retracting a gift: how does employee effort respond to wage reductions?, Journal of Labor Economics [online] 25(4): 1-37. [Cited 11 October 2012]. Available from Internet: http://www.darinlee.net/pdfs/ Lee_Rupp.pdf

Macario, R.; Reis, V.; Viegas, J., et al. 2007. The consequences of the growing European low-cost airline sector, in Requested study by the European Parliament's Committee on Transport and Tourism [online]. Brussels: European Parliament. [Cited 28 May 2012]. Available from Internet: http:// bookshop.europa.eu/en/the-consequences-of-the-growing-european-low-cost-airline-sector-pbBA3008255/?Cata$\log$ CategoryID $=$ m3UKABstAj4AAAEjh4cY4e $5 \mathrm{~K}$

Nadja, C. 2003. Low-cost carriers and low fares: competition and concentration in the U.S. airline industry [online]. Department of Economics. Stanford University. [Cited 27 July 2012]. Available from Internet: http://economics.stanford. edu/files/Theses/Theses_2003/Najda.pdf

Oum, T. H.; Yu, C. 1995. A productivity comparison of the world's major airlines, Journal of Air Transport Management 2(3-4): 181-195.

http://dx.doi.org/10.1016/0969-6997(96)00007-5

Oum, T. H.; Yu, C. 1998. An analysis of profitability of the world's major airlines, Journal of Air Transport Management 4(4): 229-237.

http://dx.doi.org/10.1016/S0969-6997(98)00023-4

Oum, T. H.; Fu, X.; Yu, C. 2005. New evidences on airline efficiency and yields: a comparative analysis of major North American air carriers and its implications, Transport Policy 12(2): 153-164.

http://dx.doi.org/10.1016/j.tranpol.2005.01.002

Pels, E. 2008. Airline network competition: full-service airlines, low-cost airlines and long-haul markets, Research in Transportation Economics 24: 68-74. http://dx.doi.org/10.1016/j.retrec.2009.01.009

Randøy, T.; Strandenes, S. P. 1997. The effect of public ownership and deregulation in the Scandinavian airline industry, Journal of Air Transport Management 3(4): 211-215. http://dx.doi.org/10.1016/S0969-6997(97)00028-8

Rose, J.; Hensher, D.; Greene, W. 2005. Recovering costs through price and service differentiation: accounting for exogenous information on attribute processing strategies in airline choice, Journal of Air Transport Management 11(6): 400-407. http://dx.doi.org/10.1016/j.jairtraman.2005.05.005

Santana, I. 2009. Do Public Service Obligations hamper the cost competitiveness of regional airlines?, Journal of Air Transport Management 15(6): 344-349. http://dx.doi.org/10.1016/j.jairtraman.2008.12.001 
Secretary of State for Transport. 2008. Comparative analysis of costs of scale in the principal european airports. Studies and norms [online]. General Directory of Civil Aviation. Ministry of Public Works. Spanish Government. October 2008. [Cited 27 July 2012]. Available from Internet: http://www.fomento.es/MFOM.CP.Web/detallepublicacion. aspx?idpub=TA0064

Swan, W. M.; Adler, N. 2006. Aircraft trip cost parameters: a function of stage length and seat capacity, Transportation Research Part E: Logistics and Transportation Review 42(2): 105-115. http://dx.doi.org/10.1016/j.tre.2005.09.004

Tiernan, S.; Rhoades, D.; Waguespack, B. 2008. Airline alliance service quality performance - an analysis of US and EU member airlines, Journal of Air Transport Management 14(2): 99-102.

http://dx.doi.org/10.1016/j.jairtraman.2008.02.003

Tretheway, M. 2011. Comment on 'legacy carriers fight back', Journal of Air Transport Management 17(1): 40-43. http://dx.doi.org/10.1016/j.jairtraman.2010.10.009

Tsoulakas, G.; Belobaba, P.; Swelbar, W. 2008. Cost convergence in the US airline industry: an analysis of unit costs 19952006, Journal of Air Transport Management 14(4): 179-187. http://dx.doi.org/10.1016/j.jairtraman.2008.04.005 